\title{
Green Biotechnology: A Brief Update on Plastid Genome Engineering
}

\author{
R. K. B. Bharadwaj, Sarma Rajeev Kumar, \\ and Ramalingam Sathishkumar
}

\begin{abstract}
Plant genetic engineering has become an inevitable tool in the molecular breeding of crops. Significant progress has been made in the generation of novel plastid transformation vectors and optimized transformation protocols. There are several advantages of plastid genome engineering over conventional nuclear transformation. Some of the advantages include multigene engineering by expression of biosynthetic pathway genes as operons, extremely high-level expression of protein accumulation, lack of transgene silencing, etc. Transgene containment owing to maternal inheritance is another important advantage of plastid genome engineering. Chloroplast genome modification usually results in alteration of several thousand plastid genome copies in a cell. Several therapeutic proteins, edible vaccines, antimicrobial peptides, and industrially important enzymes have been successfully expressed in chloroplasts so far. Here, we critically recapitulate the latest developments in plastid genome engineering. Latest advancements in plastid genome sequencing are briefed. In addition, advancement of extending the toolbox for plastid engineering for selected applications in the area of molecular farming and production of industrially important enzyme is briefed.
\end{abstract}

\footnotetext{
R. K. B. Bharadwaj

Plant Genetic Engineering Laboratory, Department of Biotechnology, Coimbatore, India

S. R. Kumar

Present Address: String Bio Private Ltd, IBAB Campus, Bangalore, India

Plant Genetic Engineering Laboratory, Department of Biotechnology, Bharathiar University, Coimbatore, Tamil Nadu, India

R. Sathishkumar $(\bowtie)$

Plant Genetic Engineering Laboratory, Department of Biotechnology, Bharathiar University, Coimbatore, Tamil Nadu, India

e-mail: rsathish@buc.edu.in
} 


\section{Keywords}

Enzymes $\cdot$ Lettuce $\cdot$ Molecular farming $\cdot$ Plastome $\cdot$ Tobacco $\cdot$ Vaccines

\subsection{Introduction}

The expected global population by 2050 will be approximately 9.1 billion (HighLevel Expert Forum, FAO, October 2009; http://www.fao.org). To nourish the everincreasing population, food production has to be increased simultaneously. Use of latest techniques in plant genetic engineering could help to increase the production of food crops. A range of different expression platforms have been used for heterologous production of foreign proteins having pharmaceutical, industrial, and agricultural applications (Demain and Vaishnav 2009). Among different production platforms, plants have been used as highly economical and scalable production systems for the expression of recombinant proteins, enzymes, and valuable metabolites. Plastid transformation technology has attracted strong interest for different applications in plant biology owing to several advantages compared to conventional nuclear transformation (Adem et al. 2017). The high ploidy number of chloroplast genome and compartmentalization of proteins allow high levels of foreign protein accumulation. Recombinant proteins are reported to accumulate up to several folds in total leaf soluble protein in plastids (Daniell et al. 2009a, b; Oey et al. 2009; Bock 2015). Plastid genomes are inherited through the maternal parent and thus provide a strong level of biological containment thus avoiding several ethical concerns. Integration of transgene proceeds via homologous recombination and is therefore highly precise and predictable (Verma and Daniell 2007). Another important feature of plastid transformation is that genetic machinery in chloroplast is devoid of gene silencing and other epigenetic mechanisms that interfere with stable transgene expression (Wani et al. 2010; Bock 2014). Recent advancement in plastid transformation is reviewed in (Kumar et al. 2017). In this chapter, we highlight the impact of chloroplast genome engineering on various plant biology applications. Advancement of chloroplast engineering for improving agronomic traits and plastids as platform for production high-value proteins for biofuel production is discussed.

\subsection{Recent Developments in Plastid Genome Sequencing}

Plant chloroplast genome (plastome) is a short double-stranded circular DNA of $\sim 100-250 \mathrm{~kb}$ in size. Plastome of land plants is highly conserved with two $\sim 25 \mathrm{~kb}$ inverted repeat (IR) regions that are separated from the rest of the genome into large single copy (LSC) and small single-copy regions (SSC) (Zhang et al. 2018a, b). In general, plastome includes approximately 130 genes encoding transcripts involved in carbon fixation (photosynthesis), transcription, and translation. Although plastid genome is highly conserved in plants, genome size varies across different species (Table 4.1) (Daniell et al. 2016). 
Table 4.1 List of important plants with annotated plastome

\begin{tabular}{|c|c|c|c|c|}
\hline $\begin{array}{l}\text { S1 } \\
\text { no }\end{array}$ & Name of plant & Common name & $\begin{array}{l}\text { Genome size } \\
(\mathrm{Mb})\end{array}$ & References \\
\hline 01 & $\begin{array}{l}\text { Amoтиm } \\
\text { compactum }\end{array}$ & Cardamom & 0.163 & Wu et al. (2018) \\
\hline 02 & Ananas comosus & Pineapple & 0.159 & Nashima et al. (2015) \\
\hline 03 & $\begin{array}{l}\text { Arabidopsis } \\
\text { thaliana }\end{array}$ & Thale cress & 0.154 & Sato et al. (1999) \\
\hline 04 & Artemisia аппиа & $\begin{array}{l}\text { Sweet } \\
\text { wormwood }\end{array}$ & 0.150 & Shen et al. (2017) \\
\hline 05 & Brassica napus & Canola & 0.152 & Hu et al. (2011) \\
\hline 06 & Camellia sinensis & Tea & 0.157 & Dong et al. (2018) \\
\hline 07 & Cannabis sativa & $\begin{array}{l}\text { Marijuana/ } \\
\text { hemp }\end{array}$ & 0.153 & $\begin{array}{l}\text { Oh et al. (2016) and Vergara } \\
\text { et al. (2016) }\end{array}$ \\
\hline 08 & Capsicum аппиит & Pepper & 0.156 & Raveendar et al. (2015) \\
\hline 09 & $\begin{array}{l}\text { Catharanthus } \\
\text { roseus }\end{array}$ & Periwinkle & 0.154 & Ku et al. 2013 \\
\hline 10 & Cicer arietinum & Chickpea & 0.125 & Jansen et al. (2008) \\
\hline 11 & Citrus sinensis & Orange & 0.160 & Bausher et al. (2006) \\
\hline 12 & Cocos nucifera & Coconut & 0.154 & Huang et al. (2013) \\
\hline 13 & Coffea arabica & Coffee & 0.155 & Samson et al. (2007) \\
\hline 14 & Cucumis sativus & Wild cucumber & 0.155 & Liu et al. (2016) \\
\hline 15 & Cuscuta reflexa & Giant dodder & 0.121 & Funk et al. (2007) \\
\hline 16 & $\begin{array}{l}\text { Cyamopsis } \\
\text { tetragonoloba }\end{array}$ & Clusterbean & 0.152 & Kaila et al. (2017) \\
\hline 17 & Daucus carota & Carrot & 0.155 & Ruhlman et al. (2006) \\
\hline 18 & Drimys granatenis & - & 0.160 & Cai et al. (2006) \\
\hline 19 & Eucalyptus globulus & $\begin{array}{l}\text { Tasmanian } \\
\text { bluegum }\end{array}$ & 0.160 & Steane (2005) \\
\hline 20 & Glycine max & Soybean & 0.152 & Saski et al. (2005) \\
\hline 21 & Hevea brasiliensis & Rubber & 0.161 & $\begin{array}{l}\text { Tangphatsornruang et al. } \\
\text { (2011) }\end{array}$ \\
\hline 22 & Hordeum vulgare & Barley & 0.135 & Middleton et al. (2014) \\
\hline 23 & $\begin{array}{l}\text { Jasminum } \\
\text { nudiflorum }\end{array}$ & Winter jasmine & 0.165 & Lee et al. (2007) \\
\hline 24 & Lactuca sativa & Lettuce & 0.152 & Timme et al. (2007) \\
\hline 25 & Lilium longiflorum & Tiger lily & 0.152 & Kim et al. (2017) \\
\hline 26 & Lotus japonicas & Wild legume & 0.150 & Kato et al. (2000) \\
\hline 27 & Malus hupehensis & Wild apple & 0.160 & Zhang et al. (2018a, b) \\
\hline 28 & Manihot esculenta & Cassava & 0.161 & Daniell et al. (2008) \\
\hline 29 & $\begin{array}{l}\text { Medicago } \\
\text { truncatulata }\end{array}$ & Barrel medic & 0.124 & Gurdon and Maliga (2014) \\
\hline 30 & Musa acuminate & Banana & 0.169 & Martin et al. (2013) \\
\hline 31 & Musa balbisiana & Wild banana & 0.169 & Niu et al. 2018 \\
\hline 32 & Nicotiana tabacum & Tobacco & 0.155 & Shinozaki et al. 1986 \\
\hline 33 & Nymphaea alba & Water lily & 0.159 & Goremykin et al. 2004 \\
\hline 34 & Oryza minuta & Wild rice & 0.135 & Asaf et al. 2017 \\
\hline
\end{tabular}


Table 4.1 (continued)

\begin{tabular}{|c|c|c|c|c|}
\hline $\begin{array}{l}\text { S1 } \\
\text { no }\end{array}$ & Name of plant & Common name & $\begin{array}{l}\text { Genome size } \\
(\mathrm{Mb})\end{array}$ & References \\
\hline 35 & Oryza sativa & Rice & 0.134 & Yu et al. 2017 \\
\hline 36 & Panax ginseng & Ginseng & 0.155 & Nguyen et al. 2018 \\
\hline 37 & $\begin{array}{l}\text { Pelargonium } \mathrm{x} \\
\text { hortorum }\end{array}$ & Geranium & 0.217 & Chumley et al. 2006 \\
\hline 38 & Piper coenoclatum & - & 0.160 & Cai et al. 2006 \\
\hline 39 & $\begin{array}{l}\text { Rosmarinus } \\
\text { officinalis }\end{array}$ & Rosemary & 0.152 & Chen and Hua (2018) \\
\hline 40 & Saccharum spp. & Sugarcane & 0.141 & Hoang et al. 2015 \\
\hline 41 & Salvia miltiorrhiza & Red sage & 0.151 & Qian et al. (2013) \\
\hline 42 & Secale cereale & Rye & 0.135 & Middleton et al. (2014) \\
\hline 43 & $\begin{array}{l}\text { Solanum } \\
\text { lycopersicum }\end{array}$ & Tomato & 0.155 & Wu (2016) \\
\hline 44 & Solanum tuberosum & Potato & 0.155 & Chung et al. (2006) \\
\hline 45 & Sorghum bicolor & Sorghum & 0.140 & Saski et al. (2007) \\
\hline 46 & Spinacia oleracea & Spinach & 0.150 & $\begin{array}{l}\text { Schmitz-Linneweber et al. } \\
(2001)\end{array}$ \\
\hline 47 & Triticum aestivum & Common wheat & 0.135 & Middleton et al. (2014) \\
\hline 48 & Vigna radiata & Mungbean & 0.151 & $\begin{array}{l}\text { Tangphatsornruang et al. } \\
\text { (2010) }\end{array}$ \\
\hline 49 & Vitis vinifera & Grapes & 0.160 & Jansen et al. (2006) \\
\hline 50 & Zea mays & Maize & 0.140 & Maier et al. (1995) \\
\hline 51 & Zingiber officinale & Ginger & 0.162 & Vaughn et al. (2014) \\
\hline
\end{tabular}

As mentioned above, plastome lacks recombination and exhibits a uniparental (maternal) inheritance. Conventionally, plastome sequencing was based on cloning of plastid DNA fragments to generate DNA libraries followed by long-range PCR. Alternatively a large set of DNA primers were used to amplify and sequence overlapping DNA fragments in plastid genome. With the rapid advancement in nextgeneration sequencing technology, it is becoming increasingly faster and cheaper to sequence and assemble plastomes. Although different sequencing platforms are available, Illumina and PacBio systems are widely used for sequencing of plastid genome and subsequent assembly (Chen et al. 2015; Lin et al. 2015; Jackman et al. 2016). However, several groups have reported reads generated through PacBio are often low (English et al. 2012). This was later improved by use of latest sequencing chemistry together with a hierarchical genome assembly process algorithm (Daniell et al. 2016).

Since the advancement in sequencing technology, several research groups across the world sequenced plastid genomes of different plants (Table 4.1). Till date, $~ 650$ plant species have their plastid genome sequence publically available in GenBank database. Plastome of two rice varieties (Oryza sativa indica and O. sativa japonica) were sequenced, and authors reported that divergence of plastome of both varieties occurred approximately 86,000 to 200,000 years ago (Tang et al. 2004). Tong et al. (2016) reported variation in chloroplast genome of rice ecotypes from Asia and Africa. Sequencing of plastid genomes of wild rice Oryza australiensis and Zizania latifolia gave insights about evolution of rice varieties (Wu and Ge 2016; Zhang 
et al. 2016). Plastomes of wheat, rye, barley, and other Triticeae species were sequenced using Roche/454 technology. Sequence alignments revealed exchange of genetic material by translocation of segment of plastome to the nuclear genome specific to rye/wheat lineage (Middleton et al. 2014). Kim et al. (2014) reported AT-rich plastid genome in orchid Cypripedium japonicum and proposed importance of AT residues in effective splicing of the plastid genome. Plastome analysis of banana Musa acuminate revealed IR/SSC expansion occurred independently multiple times in monocots during course of evolution (Martin et al. 2013).

In addition to cereals, plastome of vegetables and horticultural crops has been sequenced (reviewed in Rogalski et al. 2015). Comparisons of chloroplast genome structure between tomato (Solanum lycopersicum) and a wild diploid potato species (Solanum bulbocastanum) revealed that, at gene order, these genomes are identical, and this conservation extends even to more distantly related genera (like tobacco and Atropa) (Daniell et al. 2006). Analysis of carrot plastid genome revealed presence of several dispersed direct and inverted repeats scattered throughout coding and noncoding regions (Ruhlman et al. 2006). A comparative plastome analysis of grapes from different geographical locations revealed insights in origin and molecular basis of evolution of Vitis (Pipia et al. 2017).

Parasitic plants are interesting host to understand the evolutionary adaptation and $\sim 1 \%$ of all known angiosperm species being parasitic plants (Westwood et al. 2010). Plastid genome analysis of several parasitic plants revealed evolutionary reduction in genome size is associated with gene loss (Funk et al. 2007; Gruzdev et al. 2016). It has been proposed that DNA in plastid loci could be horizontally acquired from its host as a result of parasitism (Molina et al. 2014). This is further supported by that finding that plasmodesmatal continuity between partners allows movement of genetic material (Birschwilks et al. 2006; Roney et al. 2007; Talianova and Janousek 2011). Thus comparative plastome analysis revealed information about simplification of plastid gene expression machinery in parasitic plants. The availability of the complete plastid genome sequence for several plant species facilitated generation of novel plastid expression vectors for efficient foreign gene expression in plants through utilization of endogenous flanking sequences and regulatory elements.

\subsection{Plastid Bioreactors for Molecular Farming}

Advancement in genetic engineering has revolutionized the use of therapeutically and pharmaceutically valuable proteins in a variety of clinical treatments (Grevich and Daniell 2005). In industrial scale, an ideal expression platform should produce safe and biologically active protein (with appropriate post-translational modification) at the lowest cost. Chloroplast engineering offers great promise for both agriculture and pharmaceutical industries, for production of recombinant proteins of interest in plants is emerging as an economical and safe alternative to bacterial, yeast, or animal expression platform (Daniell 2006). Several proteins have been produced in transplastomic plants in the last two decades (Tables 4.2 and 4.3). 
Table 4.2 Selected list of vaccine antigens and therapeutic proteins produced in plants by chloroplast genome engineering

\begin{tabular}{|c|c|c|c|c|}
\hline $\begin{array}{l}\text { Sl } \\
\text { no }\end{array}$ & Name of enzyme & Gene source & Host & References \\
\hline 01 & Anti-HIV microbicide griffithsin & Griffithsia sp & Tobacco & $\begin{array}{l}\text { Hoelscher } \\
\text { et al. (2018) }\end{array}$ \\
\hline 02 & Human factor VIII (FVIII) & Human & Tobacco & $\begin{array}{l}\text { Kwon et al. } \\
(2018)\end{array}$ \\
\hline 03 & $\begin{array}{l}\text { Tetravalent EDIII antigen } \\
\text { (EDIII-1-4) }\end{array}$ & Dengue virus & Lettuce & $\begin{array}{l}\text { van Eerde et al. } \\
2018\end{array}$ \\
\hline 04 & CTB- factor IX & Human & Lettuce & $\begin{array}{l}\text { Herzog et al. } \\
(2017)\end{array}$ \\
\hline 05 & CTB-VP1 & Poliovirus & Tobacco & $\begin{array}{l}\text { Chan et al. } \\
(2016)\end{array}$ \\
\hline 06 & Capsid protein (VP1) & Poliovirus & Lettuce & $\begin{array}{l}\text { Daniell et al. } \\
(2016)\end{array}$ \\
\hline 07 & $\begin{array}{l}\text { Envelope protein domain } \\
\text { III-based antigens }\end{array}$ & Dengue virus & Tobacco & $\begin{array}{l}\text { Gottschamel } \\
\text { et al. (2016) }\end{array}$ \\
\hline 08 & gp120 and gp41 & HIV & Tobacco & $\begin{array}{l}\text { Rubio-Infante } \\
\text { et al. (2015) }\end{array}$ \\
\hline 09 & Protective antigen & Bacillus anthracis & Tobacco & $\begin{array}{l}\text { Gorantala et al. } \\
\text { (2014) }\end{array}$ \\
\hline 10 & HPV-16 L1 & Human papillomavirus & Tobacco & $\begin{array}{l}\text { Hassan et al. } \\
(2014)\end{array}$ \\
\hline 11 & E7 antigen & Human papillomavirus & Tobacco & $\begin{array}{l}\text { Morgenfeld } \\
\text { et al. (2014) }\end{array}$ \\
\hline 12 & $\begin{array}{l}\text { ESAT-6 (6 kDa early secretory } \\
\text { antigenic target), Mtb72F (a } \\
\text { fusion polyprotein from two TB } \\
\text { antigens, Mtb32 and Mtb39), and } \\
\text { LipY (a cell wall protein) }\end{array}$ & $\begin{array}{l}\text { Mycobacterium } \\
\text { tuberculosis }\end{array}$ & $\begin{array}{l}\text { Lettuce/ } \\
\text { tobacco }\end{array}$ & $\begin{array}{l}\text { Lakshmi et al. } \\
(2013)\end{array}$ \\
\hline 13 & $\begin{array}{l}\text { E protein (junction site of } \\
\text { domains I and II) }\end{array}$ & Dengue virus & Lettuce & $\begin{array}{l}\text { Maldaner et al. } \\
(2013)\end{array}$ \\
\hline 14 & $\begin{array}{l}\text { Human granulocyte colony- } \\
\text { stimulating factor (hG-CSF) }\end{array}$ & Human & Lettuce & $\begin{array}{l}\text { Sharifi Tabar } \\
\text { et al. (2013) }\end{array}$ \\
\hline 15 & CTB-proinsulin & Human & Tobacco & \begin{tabular}{|l|} 
Boyhan and \\
Daniell (2011)
\end{tabular} \\
\hline 16 & $\begin{array}{l}\text { Premembrane (prM) and } \\
\text { truncated envelope (E) protein }\end{array}$ & Dengue virus & Lettuce & $\begin{array}{l}\text { Kanagaraj } \\
\text { et al. (2011) }\end{array}$ \\
\hline 17 & $\begin{array}{l}\text { Malarial vaccine antigens apical } \\
\text { membrane antigen-1 (AMA1) } \\
\text { and merozoite surface protein-1 } \\
\text { (MSP1) fused with cholera } \\
\text { toxin-B subunit }\end{array}$ & $\begin{array}{l}\text { Plasmodium } \\
\text { falciparum }\end{array}$ & $\begin{array}{l}\text { Lettuce/ } \\
\text { tobacco }\end{array}$ & $\begin{array}{l}\text { Davoodi- } \\
\text { Semiromi et al. } \\
(2010)\end{array}$ \\
\hline 18 & Insulin-like growth factor & Human & Tobacco & $\begin{array}{l}\text { Daniell et al. } \\
(2009 b)\end{array}$ \\
\hline 19 & Envelope protein A27L & Vaccinia virus & Tobacco & $\begin{array}{l}\text { Rigano et al. } \\
(2009)\end{array}$ \\
\hline 20 & Pr55 gag & HIV-1 & Tobacco & $\begin{array}{l}\text { Scotti et al. } \\
(2009)\end{array}$ \\
\hline
\end{tabular}


Table 4.2 (continued)

\begin{tabular}{l|l|l|l|l}
\hline $\begin{array}{l}\text { S1 } \\
\text { no }\end{array}$ & Name of enzyme & Gene source & Host & References \\
\hline 21 & p24 & HIV-1 & Tobacco & $\begin{array}{l}\text { McCabe et al. } \\
(2008)\end{array}$ \\
\hline 22 & p24-Nef & HIV-1 & $\begin{array}{l}\text { Tobacco/ } \\
\text { tomato }\end{array}$ & $\begin{array}{l}\text { Zhou et al. } \\
(2008)\end{array}$ \\
\hline 23 & Viral capsid antigen & Epstein-Barr virus & Tobacco & $\begin{array}{l}\text { Lee et al. } \\
(2006)\end{array}$ \\
\hline 24 & SARS-CoV spike protein & $\begin{array}{l}\text { Synthetic gene } \\
\text { corresponding to } \\
\text { homologue protein in } \\
\text { SARS virus }\end{array}$ & $\begin{array}{l}\text { Lettuce/ } \\
\text { tobacco }\end{array}$ & Li et al. (2006) \\
\hline 25 & E2 protein & Hepatitis E virus & Tobacco & $\begin{array}{l}\text { Zhou et al. } \\
(2006)\end{array}$ \\
\hline
\end{tabular}

Table 4.3 List of industrially important enzymes/biomaterials produced by plastome engineering

\begin{tabular}{|c|c|c|c|c|}
\hline $\begin{array}{l}\text { Sl } \\
\text { no }\end{array}$ & Name of enzyme & Gene source & Host & References \\
\hline 01 & Polyhydroxybutyrate & Ralstonia eutropha & Tomato & $\begin{array}{l}\text { Mozes-Koch } \\
\text { et al. (2017) }\end{array}$ \\
\hline 02 & $\begin{array}{l}\beta \text {-Glucosidase, xylanase, } \\
\text { and endoglucanase }\end{array}$ & Trichoderma reesei & Tobacco & $\begin{array}{l}\text { Castiglia et al. } \\
\text { (2016) }\end{array}$ \\
\hline 03 & $\begin{array}{l}\text { Cellulases and } \\
\text { polygalacturonase }\end{array}$ & $\begin{array}{l}\text { Chaetomium globosum/ } \\
\text { Paenibacillus } \mathrm{sp} \text {./ } \\
\text { Phanerochaete chrysosporium }\end{array}$ & Tobacco & $\begin{array}{l}\text { Longoni et al. } \\
\text { (2015) }\end{array}$ \\
\hline 04 & Xylanase & Bacillus sp. & Tobacco & $\begin{array}{l}\text { Pantaleoni } \\
\text { et al. (2014) }\end{array}$ \\
\hline 05 & Cellulase & Thermotoga maritima & Tobacco & $\begin{array}{l}\text { Jung et al. } \\
\text { (2013) }\end{array}$ \\
\hline 06 & $\beta$-1,4-endoglucanase & Pyrococcus horikoshii & Tobacco & $\begin{array}{l}\text { Nakahira et al. } \\
\text { (2013) }\end{array}$ \\
\hline 07 & Cutinase and swollenin & Fusarium solani/T. reesei & Tobacco & $\begin{array}{l}\text { Verma et al. } \\
\text { (2013) }\end{array}$ \\
\hline 08 & Agglutinin & Pinellia ternata & Tobacco & $\begin{array}{l}\text { Jin et al. } \\
(2012)\end{array}$ \\
\hline 09 & $\beta$-Mannanase & T. reesei & Tobacco & $\begin{array}{l}\text { Agrawal et al. } \\
\text { (2011) }\end{array}$ \\
\hline 10 & Cellulase & Thermobifida fusca & Tobacco & $\begin{array}{l}\text { Petersen and } \\
\text { Bock (2011) }\end{array}$ \\
\hline 11 & Cellulase & Thermobifida fusca & Tobacco & $\begin{array}{l}\text { Gray et al. } \\
(2009)\end{array}$ \\
\hline 12 & Chitinase & Brassica juncea & Tobacco & $\begin{array}{l}\text { Guan et al. } \\
(2008)\end{array}$ \\
\hline 13 & Choline monooxygenase & Beta vulgaris & Tobacco & $\begin{array}{l}\text { Zhang et al. } \\
\text { (2008) }\end{array}$ \\
\hline 14 & Cellulase & Acidothermus cellulolyticus & Tobacco & $\begin{array}{l}\text { Jin et al. } \\
(2003)\end{array}$ \\
\hline 15 & $\begin{array}{l}\text { Bioelastic protein-based } \\
\text { polymers (PBP) }\end{array}$ & PBP gene (synthetic) & Tobacco & $\begin{array}{l}\text { Guda et al. } \\
(2000)\end{array}$ \\
\hline
\end{tabular}


Targeted transformation to plastid genome was thought to be highly challenging in plants as a typical leaf contains more than 2000 copies of the plastid genome with more than 100 chloroplasts (reviewed in Kumar et al. 2017). Nevertheless, the success achieved in green algae Chlamydomonas was also achieved in model plant tobacco (Svab et al. 1990; Svab and Maliga 1993). Since then, these two platforms remained the models for plastid transformation for production of several therapeutic proteins and industrially important enzymes. Nevertheless, progress of plastid transformation in agriculturally relevant crops like cereals and monocots is in its infancy (Maliga and Bock 2011; Rigano et al. 2012; Bock 2014). The availability of sequences of plastome, generation of novel expression vectors and development of plastid transformation protocols in crop plants extended use of chloroplast engingeering in economically important species.

Human papillomavirus (HPV) is the causative agent of cervical cancer, and HPV-E7 antigen is one of the major candidates for therapeutic vaccine production. For heterologous production of E7 in tobacco plastids, the expression of E7 as a translational fusion to $\beta$-glucuronidase enzyme was attempted. In addition, redirection of E7 into thylakoid lumen was also tried. The use of $\beta$-glucuronidase as a fusion protein turned out to be a successful strategy for improving E7 accumulation, and recombinant proteins accumulated 40 times relative to unfused E7 (Morgenfeld et al. 2014). A high-risk HPV-16 candidate therapeutic vaccine (LALF32-51-E7) was developed by plastid targeting and resulted in 27-fold higher expression compared to cytosolic targeting in Nicotiana benthamiana. The authors proposed plastids-based production could be a more affordable therapeutic vaccine for HPV16 (Yanez et al. 2018). Basic fibroblast growth factor (bFGF) accelerates cell proliferation and differentiation and hence possesses wide clinical applications. A codon-optimized bFGF gene was transformed to tobacco chloroplasts, and recombinant protein accumulation was observed (Wang et al. 2015). Serum antibodies developed in hemophilia B patients against coagulation factor IX (FIX) is highly challenging to eliminate due to nephrotic syndrome after continued infusion. Su et al. (2015) fused FIX with a transmucosal carrier (CTB) in lettuce chloroplast, and recombinant proteins accumulated up to $\sim 1 \mathrm{mg} / \mathrm{g}$. Moreover it was also demonstrated that feeding transgenic lettuce to hemophilia B mice delivered CTB-FIX effectively and not only induced $\mathrm{LAP}(+)$ regulatory T-cells but also suppressed IgE formation, anaphylaxis against FIX.

Toxoplasma gondii is an obligate intracellular parasite that causes toxoplasmosis. SAG1 is the main surface antigen in T. gondii and proposed as a promising vaccine candidate to produce anti-T. gondii vaccine. Transplastomic tobacco expressing SAG1 accumulated $\sim 0.1-0.2 \mu \mathrm{g}$ protein. Further, transplastomic plants expressing a 90-kDa heat shock protein of Leishmania infantum (LiHsp83) fused to SAG1 resulted in antigen accumulation (up to 500-fold). Subsequent oral immunization of fusion protein elicited increase in levels of SAG1-specific antibodies (Albarracín et al. 2015). Similarly, Del et al. (2012) expressed T. gondii GRA4 antigen in tobacco chloroplast, and immunization elicited mucosal immune response resulting in production of specific IgA, interferon (IFN- $\gamma$ ), and interleukin (IL-4 and IL-10). Interleukin-2 (IL-2) is a T lymphocyte-derived cytokine. Tobacco expressing human 
interleukin-2 (targeted to plastids) induced in vitro proliferation of IL-2-dependent murine T lymphocytes (Zhang et al. 2014).

There are approximately 36.9 million people living worldwide with acquired immunodeficiency syndrome (AIDS) in 2017 (UNAIDS). About 5000 new infections are being reported every day. Although human immunodeficiency virus (HIV) causes one of the most deadly infectious diseases, attempts to develop an effective vaccine remain unsuccessful till date. $\mathrm{C} 4 \mathrm{~V} 3$ is a protein known to induce systemic and mucosal immune responses during HIV infection. Rubio-Infante et al. (2012) expressed a synthetic gene encoding a C4V3 in tobacco plastids. The authors demonstrated that plant-derived $\mathrm{C} 4 \mathrm{~V} 3$ elicited both systemic and mucosal antibody responses in BALB/c mice. Further, CD4+ T cell proliferation responses were also reported. The authors strongly proposed plant chloroplasts as biofactories to produce HIV candidate vaccines. Human transforming growth factor- $\beta 3$ (TGF $\beta 3$ ) has high therapeutic value and is used to reduce scarring during wound healing. A synthetic gene with codons optimized for plastid expression resulted in accumulation of the 13-kDa TGF $\beta 3$ polypeptide by 75 -fold in tobacco (Gisby et al. 2011).

Bacillus anthracis is the causative agent of anthrax, and vaccines are limited as most of them are potentially reactogenic (Gorantala et al. 2011). Gorantala and coworkers expressed domain IV of protective antigen gene [PA(dIV)] from $B$. anthracis in tobacco plastids leading to more than $5 \%$ of total soluble protein accumulation. Further, mice challenged with $B$. anthracis and immunized with adjuvanted plant PA(dIV) exhibited $60 \%$ and $40 \%$ protection upon intraperitoneal and oral immunizations, respectively. Expression of plague F1-V fusion antigen in chloroplasts resulted in $\sim 15 \%$ of the total soluble protein. Mice were immunized with F1-V extracts and subsequently exposed to an inhaled aerosolized Yersinia pestis. It was interesting to note that $88 \%$ of the oral F1-V mice survived aerosolized $Y$. pestis, while all control mice died within 3 days (Arlen et al. 2008). Soria-Guerra et al. (2009) expressed a fusion DPT protein encoding immune-protective epitopes of Corynebacterium diphtheriae, Bordetella pertussis, and Clostridium tetani in tobacco chloroplasts. Transplastomic lines accumulated recombinant proteins, and mice orally immunized with leaf extract accumulated IgG and secretory antibodies specific to DPT toxin in serum and mucosal tissues.

Human thioredoxin $1(\mathrm{~h} \operatorname{Trx} 1)$ is a stress-responsive protein that functions as an antioxidant during oxidative stress. Lettuce expressing $h \operatorname{Tr} x l$ in chloroplast accumulated upto $1 \%$ total soluble protein and recombinant protein protected mouse insulinoma line 6 cells from peroxide-induced damage (Lim et al. 2011). Daniell et al. (2009a, b) reported expression of insulin-like growth factor-1 (IGF-1) in transgenic tobacco chloroplasts, and IGF-1 accumulation reached close to 11 total soluble proteins in transplastomic lines. Transplastomic lettuce and tobacco lines expressing cholera toxin B subunit-human proinsulin (CTB-Pins) fusion protein accumulated up to $\sim 16 \%$ and $2.5 \%$, respectively, in tobacco and lettuce. Oral administration of CTB-Pins extract exhibited decreased infiltration of cells characteristic of lymphocytes (insulitis). Further, increased expression of IL-4 and IL-10 was observed in the pancreas of CTB-Pins-treated mice (Ruhlman et al. 2007). 


\subsection{Plastid as a Biofactory for Industrially Important Enzymes, Metabolites, and Enzyme Cocktails for Biofuel Production}

Overproduction of industrially important enzymes through conventional nuclear transformation has met with little success as many reports suggest that recombinant enzymes can negatively affect transgenic plant growth and development. A gene encoding thermostable xylanase enzyme from Bacillus sp. when overexpressed in tobacco resulted in accumulation of xylanase up to $6 \%$ of the total soluble protein (Leelavathi et al. 2003). Similarly, Kim et al. (2011) demonstrated GH10 xylanase Xyl10B from Thermotoga maritima expressed in plastids exhibited high stability and catalytic activities. Further, endoglucanases like endo- $\beta-1,4-x y l a n a s e$ and $\beta$-glucosidase expressed in tobacco plastids accumulated more than $75 \%$ of total soluble proteins. Subsequent bioconversion experiments confirmed that plastidderived enzymes were able to hydrolyze industrially pretreated giant reed biomass (Castiglia et al. 2016). Pyrococcus horikoshii hyperthermostable archaeal $\beta-1,4-$ endoglucanase expressed in tobacco plastids produced high levels of active enzymes that were even recovered from dry tissues (Nakahira et al. 2013). Another study reported transplastomic plants expressing four different thermostable cell walldegrading enzymes from Thermobifida fusca accumulated up to $40 \%$ of total soluble protein. However, transplastomic lines exhibited pigment-deficient phenotypes (Petersen and Bock 2011). Klinger et al. (2015) proposed that enzymes of prokaryotic origin are efficiently expressed in plants than in a bacterial production platform. Espinoza-Sánchez et al. (2015) expressed pectin lyase and manganese peroxidase in tobacco plastids and recombinant enzymes exhibited improved enzyme activity. In another study, it was demonstrated that thermostable cellulases (Cel6A and Cel6B) from Thermobifida fusca expressed in tobacco chloroplasts were able to hydrolyze crystalline cellulose (Yu et al. 2007).

Plastome has been successfully engineered to produce important biomaterials. Bioelastic protein-based polymers (PBP) have huge industrial applications. These polymers are often used in soft tissue augmentation and regeneration. A synthetic PBP was targeted to both nucleus and plastids. It was confirmed that PBP transcripts accumulated up to 100-fold higher in transplastomic lines compared to nuclear transgenic plants (Guda et al. 2000). Despite the diversion of major metabolic pathway intermediate, metabolic engineering using chloroplast genomes led to production of several bioplastics. Bacterial genes encoding the polyhydroxybutyrate (PHB) pathway encoding enzymes were expressed in tobacco plastome. Transplastomic lines produced $\sim 18.8 \%$ dry weight PHB (Bohmert-Tatarev et al. 2011). Another study reported expression of Ralstonia eutropha polyhydroxybutyrate operon in plastids and transplastomic lines produced biodegradable PHB (Mozes-Koch et al. 2017). Engineering chloroplast genome resulted in advancement of different biotechnological applications including production of thermostable industrial enzymes, biomaterials, and immunologicals. Nonetheless, how many of these will be approved for commercial level production and will reach market is still a matter of debate. 
One of the important applications of plastid transformation is for the expression of enzyme for biofuel production. With the growing interest in biofuels, enzyme cocktails that can digest lignocellulosic biomass into fermentable sugars have gained much attention. A major breakthrough in biofuel production was the report from Verma et al. (2010) about chloroplast-derived enzyme cocktails for the production of fermentable sugars from different sources of lignocellulosic materials. The authors reported that cost of plastid-derived endoglucanase was estimated to be 3000-fold lower than for the same commercially available recombinant enzymes (Verma et al. 2010). Verma et al. (2013) demonstrated treatment of cotton fiber with plastid produced cutinase exhibited enlarged segments and the intertwined inner fibers due to activity of cutinase. In addition, recombinant protein showed improved esterase and lipase activity in addition to its cutinase activity. Endo- $\beta$-mannanase enzyme cocktail mixture derived from chloroplast exhibited $20 \%$ more glucose equivalents formation from pinewood compared to cocktail without mannanase (Agrawal et al. 2011). Verma et al. (2010) reported plastid-derived enzyme cocktails yielded more than $3625 \%$ glucose from substrates like citrus peel and pine wood than commercially available enzyme cocktails. Transplastomic plants accumulating cell wall-degrading enzymes will be an alternate and cheap renewable source of enzymes for the production of cellulosic ethanol in the near future.

\subsection{Updates on Plastid Transformation toward Improving Agricultural Traits}

Chloroplast genome engineering has led to stable integration and expression of transgenes to confer valuable agronomic traits (Daniell et al. 2002; Maliga and Block 2011; and Jin and Daniell 2015). Poage et al. (2011) demonstrated expression of mitochondrial superoxide dismutase and E.coli glutathione reductase through plastid transformation in tobacco. The transformed lines exhibited increased radical scavenging activity thereby increasing tolerance to heavy metal stress and UV-B radiation. Expression of genes involved in secondary metabolites production has been demonstrated through plastid transformation. Tocochromanol pathway is introduced to plastids as single gene constructs into tobacco and tomato plants which resulted in tenfold higher accumulation of tocochromanol compared to controls (Lu et al. 2013). Plastomic transformation of acetolactate synthase (ALS) gene which catalyzes the first step in branched chain amino acid biosynthesis into the Arabidopsis thaliana conferred resistance against herbicides such as pyrimidinylcarboxylate and imidazolinon (Shimizu et al. 2008). Overexpression of cry9Aa2 (insecticidal protein) in chloroplasts of tobacco plants conferred resistance against Phthorimaea operculella (potato tuber moth), but this higher expression of protein delayed plant growth and development (Chakrabarti et al. 2006). Similarly, expression of cry1Ac protein through chloroplast transformation in rice resulted in enhanced resistance against common pests of rice skipper and caterpillar (Kim et al. 2009). In another study, transformation of Pseudomonas pyrrocinia chloroperoxidase when expressed in tobacco plastids not only resulted in accumulation of recombinant protein but also improved 
resistance toward Alternaria Alternata, Aspergillus flavus, Fusarium sp., and Verticillium sp. (Ruhlman et al. 2014).

Fathi Roudsari et al. (2009) generated improved glyphosate-resistant tobacco plants through biolistic transformation of chloroplasts by introducing a mutated herbicide-tolerant gene coding for EPSP synthase. p-Hydroxybenzoic acid (pHBA) is the major monomer in liquid crystal polymers. E. coli ubiC encoding chorismate pyruvate-lyase (CPL) was transformed to tobacco plastome. Total CPL accumulated up to $35 \%$ of total soluble protein and was 250 times higher compared to nuclear integration events. Authors reported that CPL integration to chloroplast genome provides a proof of concept of the high-flux potential of shikimate pathway for chorismate biosynthesis and also as a cost-effective route to pHBA production (Viitanen et al. 2004).

Astaxanthin is a rich antioxidant and occurs naturally in certain algae that underlie the red coloration of salmon and other organisms. Expression of different genes including $\beta$-carotene ketolase, $\beta$-carotene hydroxylase, and isopentenyl diphosphate isomerase from marine bacteria in lettuce plastome led to accumulation of astaxanthin fatty acid esters (Harada et al. 2014).Vitamin E ( $\alpha, \beta, \gamma$, and $\delta$-tocopherols) are lipid-soluble antioxidants. Tocopherol biosynthetic machinery in plastids utilized precursors derived from two different metabolic pathways, homogentisic acid, an intermediate of shikimate pathway, and phytyldiphosphate, intermediate from methylerythritol phosphate pathway (Lushchak and Semchuk 2012). Expression of $\gamma$-tocopherol methyltransferase $(\gamma$-TMT) and tocopherol cyclase (TC) in tobacco and lettuce plastids resulted in improved $\alpha$-tocopherol levels (Yabuta et al. 2013). Plastome expression of homogentisate phytyltransferase (HPT), TC, and $\gamma$-TMT confirmed HPT as the rate-limiting enzymatic step in tocopherol biosynthesis (Lu et al. 2013). Wurbs et al. (2007) demonstrated plastid expression of a bacterial lycopene $\beta$-cyclase in tomato-mediated conversion of lycopene to $\beta$-carotene and resulted in fourfold enhanced provitamin A content in fruits. Apel and Bock (2009) produced transplastomic tomato by overexpressing $\beta$-cyclase that resulted in an increase of up to $50 \%$ in provitamin A. Further, transplastomic plants accumulated $\sim 50 \%$ increase in total carotenoid, and this could be possible by enhancing the flux through the pathway in chromoplasts. Overall, these findings highlight the potential of chloroplast engineering for production of high-value metabolites in plastid biofactories.

RNA interference (RNAi) technology was used for the first time to engineer the chloroplast genome by Jin et al. (2015). A lepidopteran chitin synthase (Chi), cytochrome P450 monooxygenase (CYP450), and V-ATPase were used as RNAi targets by the above group of researchers. In insects feeding assay in leaves of transplastomic lines, CYP450, Chi, and V-ATPase siRNAs, transcript levels were reduced to undetectable levels in insect midgut. In addition, net weight of the larvae and their growth and pupation were significantly reduced indicating success of technology. Zhang et al. (2015) introduced dsRNA via the chloroplast genome to target the insect $\beta$-actin gene and to subsequently elicit resistance against potato beetle. Transgenic potato lines producing dsRNAs targeted against the $\beta$-actin gene of the Colorado potato beetle, a deadlier agricultural pest, were successful. Chloroplast expression of long dsRNAs provided protection of potato lines without application of chemical 
pesticides. A construct encoding 200-nucleotide duplex-stemmed-hairpin (hp) RNAs, targeting the cholinesterase gene of Helicoverpa armigera (cotton bull worm), was targeted to both nuclear and plastid genome of $N$. benthamiana. Undiced, full-length hairpin RNAs (hpRNA) accumulated in N. benthamiana and conferred strong protection against $H$. armigera herbivory (Bally et al. 2016). Overall, successful expression of dsRNAs through plastome engineering opens the great possibility of using RNAi approaches to confer desired agronomic traits in plants.

\subsection{Concluding Remarks and Future Focus}

Engineering of plastid genome has taken a huge leap in plant biology owing to several advantages over nuclear genome engineering. In addition, recent availability of plastid genome sequence of many plants resulted in broadening the host range just from tobacco and lettuce to other crops like tomato, carrot, potato, cotton, soybean, etc. Despite the several advancements made in plastid transformation, there are still several major concerns that need to be addressed. One of the main disadvantages of plastome engineering is related to post-translational modification. Plastids lack the necessary machinery to glycosylate proteins, and absence of glycosylation is one of the major bottlenecks for the proper folding and functioning of glycoproteins like antibodies. Another major concern is stability of recombinant proteins in plastids. Chloroplast stroma contains several proteases that could degrade recombinant proteins produced. The expression of transgenes in non-green plastids is not as efficient as in green plastids (chloroplasts), and challenges related to poor gene expression in non-green plastid are still a major concern. Although the last two decades witnessed expression of a large number of vaccine antigens and therapeutic proteins in plastids (Table 4.2), hardly any chloroplast-made proteins completed clinical trials. This is due to the strict regulatory and IP issues related to the use of plant-made proteins for human consumption. Nevertheless, addressing some of the above concerns could lead to a new paradigm in plastome engineering and could contribute for the development of sustainable production of therapeutic proteins and industrial enzyme in plastids for human consumption and commercial exploitation, respectively.

Acknowledgment The authors thank financial support to Department of Biotechnology, Bharathiar University, under DST- PURSE scheme.

\section{References}

Adem M, Beyene D, Feyissa T (2017) Recent achievements obtained by chloroplast transformation. Plant Methods 13:30

Agrawal P, Verma D, Daniell H (2011) Expression of Trichoderma reesei $\beta$-mannanase in tobacco chloroplasts and its utilization in lignocellulosic woody biomass hydrolysis. PLoS One 6:e29302

Albarracín RM, Becher ML, Farran I, Sander VA, Corigliano MG, Yácono ML, Pariani S, López ES, Veramendi J, Clemente M (2015) The fusion of Toxoplasma gondii SAG1 vaccine candi- 
date to Leishmania infantum heat shock protein 83-kDa improves expression levels in tobacco chloroplasts. Biotechnol J 10:748-759

Apel W, Bock R (2009) Enhancement of carotenoid biosynthesis in transplastomic tomatoes by induced lycopene-to-provitamin A conversion. Plant Physiol 151:59-66

Arlen PA, Singleton M, Adamovicz JJ, Ding Y, Davoodi-Semiromi A, Daniell H (2008) Effective plague vaccination via oral delivery of plant cells expressing F1-V antigens in chloroplasts. Infect Immun 76:3640-3650

Asaf S, Waqas M, Khan AL, Khan MA, Kang SM, Imran QM, Shahzad R, Bilal S, Yun BW, Lee IJ (2017) The complete chloroplast genome of wild rice (Oryza minuta) and its comparison to related species. Front Plant Sci 8:304

Bally J, McIntyre GJ, Doran RL, Lee K, Perez A, Jung H, Naim F, Larrinua IM, Narva KE, Waterhouse PM (2016) In-plant protection against Helicoverpa armigera by production of long hpRNA in chloroplasts. Front Plant Sci 7:1453

Bausher MG, Singh ND, Lee SB, Jansen RK, Daniell H (2006) The complete chloroplast genome sequence of Citrus sinensis (L.) Osbeck var 'Ridge Pineapple': organization and phylogenetic relationships to other angiosperms. BMC Plant Biol 6:21

Birschwilks M, Haupt S, Hofius D, Neumann S (2006) Transfer of phloem-mobile substances from the host plants to the holoparasite Cuscuta sp. J Exp Bot 57:911-921

Bock R (2014) Genetic engineering of the chloroplast: novel tools and new applications. Curr Opin Biotechnol 26:7-13

Bock R (2015) Engineering plastid genomes: methods, tools, and applications in basic research and biotechnology. Annu Rev Plant Biol 66:31-33

Bohmert-Tatarev K, McAvoy S, Daughtry S, Peoples OP, Snell KD (2011) High levels of bioplastic are produced in fertile transplastomic tobacco plants engineered with a synthetic operon for the production of polyhydroxybutyrate. Plant Physiol 155:1690-1708

Boyhan D, Daniell H (2011) Low-cost production of proinsulin in tobacco and lettuce chloroplasts for injectable or oral delivery of functional insulin and C-peptide. Plant Biotechnol J 9:585-598

Cai Z, Penaflor C, Kuehl JV, Leebens-Mack J, Carlson JE, de Pamphilis CW, Boore JL, Jansen RK (2006) Complete plastid genome sequences of Drimys, Liriodendron, and Piper: implications for the phylogenetic relationships of magnoliids. BMC Evolut Biol 6:77

Castiglia D, Sannino L, Marcolongo L, Ionata E, Tamburino R, De Stradis A, Cobucci-Ponzano B, Moracci M, La Cara F, Scotti N (2016) High-level expression of thermostable cellulolytic enzymes in tobacco transplastomic plants and their use in hydrolysis of an industrially pretreated Arundo donax L. biomass. Biotechnol Biofuels. 9:154

Chakrabarti SK, Lutz KA, Lertwiriyawong B, Svab Z, Maliga P (2006) Expression of the cry9Aa2 B.t. gene in tobacco chloroplasts confers resistance to potato tuber moth. Transgenic Res 15:481-488

Chan HT, Xiao Y, Weldon WC, Oberste SM, Chumakov K, Daniell H (2016) Cold chain and virus-free chloroplast-made booster vaccine to confer immunity against different poliovirus serotypes. Plant Biotechnol J 14:2190-2200

Chen C, Hua W (2018) The complete chloroplast genome of rosemary (Rosmarinus officinalis). Mitochondrial DNA Part B. Resources 4:147-148

Chen X, Li Q, Li Y, Qian J, Han J (2015) Chloroplast genome of Aconitum barbatum var. puberulum (Ranunculaceae) derived from CCS reads using the PacBio RS platform. Front Plant Sci 6:42

Chumley TW, Palmer JD, Mower JP, Fourcade HM, Calie PJ, Boore JL, Jansen RK (2006) The complete chloroplast genome sequence of Pelargonium x hortorum: organization and evolution of the largest and most highly rearranged chloroplast genome of land plants. Mol Biol Evol 23:2175-2190

Chung H-J, Jung JD, Park H-W, Kim J-H, Cha HW, Min SR, Jeong WJ, Liu JR (2006) The complete chloroplast genome sequences of Solanum tuberosum and comparative analysis with Solanaceae species identified the presence of a 241-bp deletion in cultivated potato chloroplast DNA sequence. Plant Cell Rep 25:1369-1379 
Daniell H (2006) Production of biopharmaceuticals and vaccines in plants via the chloroplast genome. Biotechnol J 1:1071-1079

Daniell H, Khan MS, Allison L (2002) Milestones in chloroplast genetic engineering: an environmentally friendly era in biotechnology. Trends Plant Sci 7:84-91

Daniell H, Lee SB, Grevich J, Saski C, Quesada-Vargas T, Guda C, Tomkins J, Jansen RK (2006) Complete chloroplast genome sequences of Solanum bulbocastanum, Solanum lycopersicum and comparative analyses with other Solanaceae genomes. Theor Appl Genet 112:1503-1518

Daniell H, Wurdack KJ, Kanagaraj A, Lee SB, Saski C, Jansen RK (2008) The complete nucleotide sequence of the cassava (Manihot esculenta) chloroplast genome and the evolution of atpF in Malpighiales: RNA editing and multiple losses of a group II intron. Theor Appl Genet 116:723-737

Daniell H, Ruiz G, Denes B, Sandberg L, Langridge W (2009a) Optimization of codon composition and regulatory elements for expression of human insulin like growth factor- 1 in transgenic chloroplasts and evaluation of structural identity and function. BMC Biotechnol 9:33

Daniell H, Singh ND, Mason H, Streatfield SJ (2009b) Plant-made vaccine antigens and biopharmaceuticals. Trends Plant Sci 14:669-679

Daniell H, Lin CS, Yu M, Chang WJ (2016) Chloroplast genomes: diversity, evolution, and applications in genetic engineering. Genome Biol 17:134-163

Davoodi-Semiromi A, Schreiber M, Nalapalli S, Verma D, Singh ND, Banks RK, Chakrabarti D, Daniell H (2010) Chloroplast-derived vaccine antigens confer dual immunity against cholera and malaria by oral or injectable delivery. Plant Biotechnol J 8:223-242

Del L, Yácono M, Farran I, Becher ML, Sander V, Sánchez VR, Martín V, Veramendi J, Clemente M (2012) A chloroplast-derived Toxoplasma gondii GRA4 antigen used as an oral vaccine protects against toxoplasmosis in mice. Plant Biotechnol J 10:1136-1144

Demain AL, Vaishnav P (2009) Production of recombinant proteins by microbes and higher organisms. Biotechnol Adv 27:297-306

Dong M, Liu S, Xu Z, Hu Z, Ku W, Wu L (2018) The complete chloroplast genome of an economic plant, Camellia sinensis cultivar Anhua, China. Mitochond DNA B Resour. https://doi.org/10. 1080/23802359.2018.1462124

English AC, Richards S, Han Y, Wang M, Vee V, Qu J, Qin X, Muzny DM, Reid JG, Worley KC, Gibbs RA (2012) Mind the gap: upgrading genomes with Pacific biosciences RS long-read sequencing technology. PLoS One 7:e47768

Espinoza-Sáncheza EA, Álvarez-Hernándeza MH, Torres-Castillob JA, Rascón-Cruzc Q, Gutiérrez-Díeza A, Zavala-Garcíaa F, Sinagawa-García SR (2015) Stable expression and characterization of a fungal pectinase and bacterial peroxidase genes in tobacco chloroplast. Electron J Biotechnol 18:161-168

Fathi Roudsari M, Salmanian AH, Mousavi A, Hashemi SH, Jafari M (2009) Regeneration of glyphosate-tolerant Nicotiana tabacum after plastid transformation with a mutated variant of bacterial aroA gene. Iran J Biotechnol 7:247-253

Funk HT, Berg S, Krupinska K, Maier UGand Krause K (2007) Complete DNA sequences of the plastid genomes of two parasitic flowering plant species, Cuscuta reflexa and Cuscuta gronovii. BMC Plant Biol 7:45

Gisby MF, Mellors P, Madesis P, Ellin M, Laverty H, O'Kane S, Ferguson MW, Day A (2011) A synthetic gene increases TGF $\beta 3$ accumulation by 75 -fold in tobacco chloroplasts enabling rapid purification and folding into a biologically active molecule. Plant Biotechnol J 9:618-628

Gorantala J, Grover S, Goel D, Rahi A, Jayadev Magani SK, Chandra S, Bhatnagar R (2011) A plant based protective antigen [PA(dIV)] vaccine expressed in chloroplasts demonstrates protective immunity in mice against anthrax. Vaccine 29:4521-4533

Gorantala J, Grover S, Rahi A, Chaudhary P, Rajwanshi R, Sarin NB, Bhatnagar R (2014) Generation of protective immune response against anthrax by oral immunization with protective antigen plant-based vaccine. J Biotechnol 176:1-10

Goremykin VV, Hirsch-Ernst KI, Wölfl S, Hellwig FH (2004) The chloroplast genome of Nymphaea alba: whole-genome analyses and the problem of identifying the most basal angiosperm. Mol Biol Evol 21:1445-1454 
Gottschamel J, Lössl A, Ruf S, Wang Y, Skaugen M, Bock R, Clarke JL (2016) Production of dengue virus envelope protein domain III-based antigens in tobacco chloroplasts using inducible and constitutive expression systems. Plant Mol Biol 91:497-512

Gray BN, Ahner BA, Hanson MR (2009) High-level bacterial cellulase accumulation in chloroplasttransformed tobacco mediated by downstream box fusions. Biotechnol Bioeng 102:1045-1054

Grevich JJ, Daniell H (2005) Chloroplast genetic engineering: recent advances and future perspectives. Crit Rev Plant Sci 24:83-107

Gruzdev EV, Mardanov AV, Beletsky AV, Kochieva EZ, Ravin NV, Skryabin KG (2016) The complete chloroplast genome of parasitic flowering plant Monotropa hypopitys: extensive gene losses and size reduction. Mitochond DNA B Resour. https://doi.org/10.1080/23802359.201 6.1155090

Guan Y, Ramalingam S, Nagegowda D, Taylor PW, Chye ML (2008) Brassica juncea chitinase BjCHI1 inhibits growth of fungal phytopathogens and agglutinates Gram-negative bacteria. J Exp Bot 59:3475-3484

Guda C, Lee S-B, Daniell H (2000) Stable expression of biodegradable protein-based polymer in tobacco chloroplasts. Plant Cell Rep 19:257-262

Gurdon C, Maliga P (2014) Two distinct plastid genome configurations and unprecedented intraspecies length variation in the accd coding region in Medicago truncatula. DNA Res 21:417-427

Harada H, Maoka T, Osawa A, Hattan J, Kanamoto H, Shindo K, Otomatsu T, Misawa N (2014) Construction of transplastomic lettuce (Lactuca sativa) dominantly producing astaxanthin fatty acid esters and detailed chemical analysis of generated carotenoids. Transgenic Res 23:303-315

Hassan SW, Waheed MT, Müller M, Clarke JL, Shinwari ZK, Lössl AG (2014) Expression of HPV-16 L1 capsomeres with glutathione-S-transferase as a fusion protein in tobacco plastids: an approach for a capsomere-based HPV vaccine. Hum Vaccin Immunother 10(10):2975-2982

Herzog RW, Nichols TC, Su J, Zhang B, Sherman A, Merricks EP, Raymer R, Perrin GQ, Häger M, Wiinberg B, Daniell H (2017) Oral tolerance induction in hemophilia B dogs fed with transplastomic Lettuce. Mol Ther 25:512-522

Hoang NV, Furtado A, McQualter RB, Henry RJ (2015) Next generation sequencing of total DNA from sugarcane provides no evidence for chloroplast heteroplasmy. New negatives. Plant Sci $1-2: 33-45$

Hoelscher M, Tiller N, Teh AY, Wu GZ, Ma JK, Bock R (2018) High-level expression of the HIV entry inhibitor griffithsin from the plastid genome and retention of biological activity in dried tobacco leaves. Plant Mol Biol 97:357-370

Hu Z-Y, Hua W, Huang S-M, Wang H-Z (2011) Complete chloroplast genome sequence of rapeseed (Brassica napus L.) and its evolutionary implications. Genet Resour Crop Evol 58:875-887

Huang YY, Matzke AJ, Matzke M (2013) Complete sequence and comparative analysis of the chloroplast genome of coconut palm (Cocos nucifera). PLoS One 8:e74736

Jackman SD, Warren RL, Gibb EA, Vandervalk BP, Mohamadi H, Chu J, Raymond A, Pleasance S, Coope R, Wildung MR, Ritland CE, Bousquet J, Jones SJ, Bohlmann J, Birol I (2016) Organellar genomes of white spruce (Picea glauca): assembly and annotation. Genome Biol Evol 8:29-41

Jansen RK, Kaittanis C, Saski C, Lee SB, Tomkins J, Alverson AJ, Daniell H (2006) Phylogenetic analyses of Vitis (Vitaceae) based on complete chloroplast genome sequences: effects of taxon sampling and phylogenetic methods on resolving relationships among rosids. BMC Evol Biol 6:32

Jansen RK, Wojciechowski MF, Sanniyasi E, Lee SB, Daniell H (2008) Complete plastid genome sequence of the chickpea (Cicer arietinum) and the phylogenetic distribution of rps12 and clpP intron losses among legumes (Leguminosae). Mol Phylogenet Evol 48:1204-1217

Jin S, Daniell H (2015) The engineered chloroplast genome just got smarter. Trends Plant Sci 20:622-640

Jin R, Richter S, Zhong R, Lamppa GK (2003) Expression and import of an active cellulase from a thermophilic bacterium into the chloroplast both in vitro and in vivo. Plant Mol Biol 51:493-507 
Jin S, Zhang X, Daniell H (2012) Pinellia ternata agglutinin expression in chloroplasts confers broad spectrum resistance against aphid, whitefly, lepidopteran insects, bacterial and viral pathogens. Plant Biotechnol J 10:313-327

Jin S, Singh ND, Li L, Zhang X, Daniell H (2015) Engineered chloroplast dsRNA silences cytochrome p450 monooxygenase, V-ATPase and chitin synthase genes in the insect gut and disrupts Helicoverpa armigera larval development and pupation. Plant Biotechnol J 13:435-446

Jung S, Lee DS, Kim YO, Joshi CP, Bae HJ (2013) Improved recombinant cellulase expression in chloroplast of tobacco through promoter engineering and $5^{\prime}$ amplification promoting sequence. Plant Mol Biol 83:317-328

Kaila T, Chaduvla PK, Rawal HC, Saxena S, Tyagi A, Mithra SVA, Solanke AU, Kalia P, Sharma TR, Singh NK, Gaikwad K (2017) Chloroplast genome sequence of clusterbean (Cyamopsis tetragonoloba $\mathrm{L}$.): genome structure and comparative analysis. Genes. 8:pii: E212. https://doi. org/10.3390/genes 8090212

Kanagaraj AP, Verma D, Daniell H (2011) Expression of Dengue-3 premembrane and envelope polyprotein in lettuce chloroplasts. Plant Mol Biol 76:323-333

Kato T, Kaneko T, Sato S, Nakamura Y, Tabata S (2000) Complete structure of the chloroplast genome of a legume, Lotus japonicus. DNA Res 7:323-330

Kim EH, Suh SC, Park BS, Shin KS, Kweon SJ, Han EJ, Park SH, Kim YS, Kim JK (2009) Chloroplast-targeted expression of synthetic cry1 Ac in transgenic rice as an alternative strategy for increased pest protection. Planta 230:397-405

Kim JY, Kavas M, Fouad WM, Nong G, Preston JF, Altpeter F (2011) Production of hyperthermostable GH10 xylanase Xyl10B from Thermotoga maritima in transplastomic plants enables complete hydrolysis of methylglucuronoxylan to fermentable sugars for biofuel production. Plant Mol Biol 76:357-369

Kim JS, Kim HT, Kim J-H (2014) The largest plastid genome of monocots: a novel genome type containing at residue repeats in the slipper orchid Cypripedium japonicum. Plant Mol Biol Report 33:1210. https://doi.org/10.1007/s11105-014-0833-y

Kim JH, Lee SI, Kim BR, Choi IY, Ryser P, Kim NS (2017) Chloroplast genomes of Lilium lancifolium, L. amabile, L. callosum, and L. philadelphicum: molecular characterization and their use in phylogenetic analysis in the genus Lilium and other allied genera in the order Liliales. PLoS One. 12:e186788

Klinger J, Fischer R, Commandeur U (2015) Comparison of Thermobifida fusca cellulases expressed in Escherichia coli and Nicotiana tabacum indicates advantages of the plant system for the expression of bacterial cellulases. Front Plant Sci 6:1047

Ku C, Chung WC, Chen LL, Kuo CH (2013) The complete plastid genome sequence of Madagascar periwinkle Catharanthus roseus (L) G. Don: plastid genome evolution, molecular marker identification, and phylogenetic implications in asterids. PLoS One 8(6):e68518

Kumar SR, Anunanthini P, Sathishkumar R (2017) Plastome engineering: yesterday, today, and tomorrow. In: Mohan C (ed) Sugarcane biotechnology: challenges and prospects, Springer, pp 139-154

Kwon KC, Sherman A, Chang WJ, Kamesh A, Biswas M, Herzog RW, Daniell H (2018) Expression and assembly of largest foreign protein in chloroplasts: Oral delivery of human FVIII made in lettuce chloroplasts robustly suppresses inhibitor formation in haemophilia a mice. Plant Biotechnol J 16:1148-1160

Lakshmi PS, Verma D, Yang X, Lloyd B, Daniell H (2013) Low cost tuberculosis vaccine antigens in capsules: expression in chloroplasts, bio-encapsulation, stability and functional evaluation in vitro. PLoS One 8:e54708

Lee MY, Zhou Y, Lung RW, Chye ML, Yip WK, Zee SY, Lam E (2006) Expression of viral capsid protein antigen against Epstein-Barr virus in plastids of Nicotiana tabacum cv. SR1. Biotechnol Bioeng 94:1129-1137

Lee HL, Jansen RK, Chumley TW, Kim KJ (2007) Gene relocations within chloroplast genomes of Jasminum and Menodora (Oleaceae) are due to multiple, overlapping inversions. Mol Biol Evol 24:1161-1180 
Leelavathi S, Gupta N, Maiti S, Ghosh A, Reddy VS (2003) Overproduction of an alkali- and thermo-stable xylanase in tobacco chloroplasts and efficient recovery of the enzyme. Mol Breed 11:59-67

Li HY, Ramalingam S, Chye ML (2006) Accumulation of recombinant SARS-CoV spike protein in plant cytosol and chloroplasts indicate potential for development of plant-derived oral vaccines. Exp Biol Med 231:1346-1352

Lim S, Ashida H, Watanabe R, Inai K (2011) Production of biologically active human thioredoxin 1 protein in lettuce chloroplasts. Plant Mol Biol 76:335-344

Lin CS, Chen JJ, Huang YT, Chan MT, Daniell H, Chang WJ, Hsu CT, Liao DC, Wu FH, Lin SY, Liao CF, Deyholos MK, Wong GK, Albert VA, Chou ML, Chen CY and Shih MC (2015). The location and translocation of ndh genes of chloroplast origin in the Orchidaceae family. Scientific Reports.5:9040

Liu B, Zhang D, Gao LZ (2016) The complete chloroplast genome sequence of Cucumis sativus var. Hardwickii, the wild progenitor of cultivated cucumber. Mitochond DNA A DNA Mapp Seq Anal 27:4627-4628

Longoni P, Leelavathi S, Doria E, Reddy VS, Cella R (2015) Production by tobacco transplastomic plants of recombinant fungal and bacterial cell-wall degrading enzymes to be used for cellulosic biomass saccharification. BioMed Research Intl 289759. https://doi.org/10.1155/2015/289759

Lu Y, Rijzaani H, Karcher D, Ruf S, Bock R (2013) Efficient metabolic pathway engineering in transgenic tobacco and tomato plastids with synthetic multigene operons. Proc Nat Acad Sci USA 110:E623-E632

Lushchak V, Semchuk NM (2012) Tocopherol biosynthesis: chemistry, regulation and effects of environmental factors. Acta Physiol Plant 34:1607-1628

Maier RM, Neckermann K, Igloi GL, Kössel H (1995) Complete sequence of the maize chloroplast genome: gene content, hotspots of divergence and fine tuning of genetic information by transcript editing. J Mol Biol 251:614-628

Maldaner FR, Aragão FJ, dos Santos FB, Franco OL, da Rocha Queiroz Lima M, de Oliveira RR, Vasques RM, Nagata T (2013) Dengue virus tetra-epitope peptide expressed in lettuce chloroplasts for potential use in dengue diagnosis. Appl Microbiol Biotechnol 97:5721-5729

Maliga P, Bock R (2011) Plastid biotechnology: food, fuel, and medicine for the 21st century. Plant Physiol 155:1501-1510

Martin G, Baurens FC, Cardi C, Aury JM, D'Hont A (2013) The complete chloroplast genome of banana (Musa acuminata, Zingiberales): insight into plastid monocotyledon evolution. PLoS One 8(6):e67350

McCabe MS, Klaas M, Gonzalez-Rabade N, Poage M, Badillo-Corona JA, Zhou F, Karcher D, Bock R, Gray JC, Dix PJ (2008) Plastid transformation of high-biomass tobacco variety Maryland Mammoth for production of human immunodeficiency virus type 1 (HIV-1) p24 antigen. Plant Biotechnol J 6:914-929

Middleton CP, Senerchia N, Stein N, Akhunov ED, Keller B, Wicker T, Kilian B (2014) Sequencing of chloroplast genomes from wheat, barley, rye and their relatives provides a detailed insight into the evolution of the Triticeae tribe. PLoS One 9:e85761

Molina J, Hazzouri KM, Nickrent D, Geisler M, Meyer RS, Pentony MM, Flowers JM, Pelser P, Barcelona J, Inovejas SA, Uy I, Yuan W, Wilkins O, Michel CI, Locklear S, Concepcion GP, Purugganan MD (2014) Possible loss of the chloroplast genome in the parasitic flowering plant Rafflesia lagascae (Rafflesiaceae). Mol Biol Evol 31:793-803

Morgenfeld M, Lentz E, Segretin ME, Alfano EF, Bravo-Almonacid F (2014) Translational fusion and redirection to thylakoid lumen as strategies to enhance accumulation of human papillomavirus E7 antigen in tobacco chloroplasts. Mol Biotechnol 56:1021-1031

Mozes-Koch R, Tanne E, Brodezki A, Yehuda R, Gover O, Rabinowitch HD, Sela I (2017) Expression of the entire polyhydroxybutyrate operon of Ralstonia eutropha in plants. J Biol Eng 11:44

Nakahira Y, Ishikawa K, Tanaka K, Tozawa Y, Shiina T (2013) Overproduction of hyperthermostable $\beta$-1,4-endoglucanase from the archaeon Pyrococcus horikoshii by tobacco chloroplast engineering. Biosci Biotechnol Biochem 77:2140-2143 
Nashima K, Terakami S, Nishitani C, Kunihisa M, Shoda M, Takeuchi M, Urasaki N, Tarora K, Yamamoto T, Katayama H (2015) Complete chloroplast genome sequence of pineapple (Ananas comosus). Tree Genet Genomes 11:60

Nguyen VB, Giang NL, Waminal NE, Park H-S, Kim N-H, Jang W, Lee J, Yang T-J (2018) Comprehensive comparative analysis of chloroplast genomes from seven Panax species and development of an authentication system based on species-unique single nucleotide polymorphism markers. J Gingseng Res. https://doi.org/10.1016/j.jgr.2018.06.003

Niu Y-F, Gao C-W, Liu J (2018) The complete chloroplast genome sequence of wild banana, Musa balbisiana variety 'Pisang Klutuk Wulung' (Musaceae). DNA Res 3:460-461

Oey M, Lohse M, Kreikemeyer B, Bock R (2009) Exhaustion of the chloroplast protein synthesis capacity by massive expression of a highly stable protein antibiotic. Plant J 57:436-445

Oh H, Seo B, Lee S, Ahn DH, Jo E, Park JK, Min GS (2016) Two complete chloroplast genome sequences of Cannabis sativa varieties. Mitochond DNA A DNA Mapp Seq Anal 27:2835-2837

Pantaleoni L, Longoni P, Ferroni L, Baldisserotto C, Leelavathi S, Reddy VS, Pancaldi S, Cella R (2014) Chloroplast molecular farming: efficient production of a thermostable xylanase by Nicotiana tabacum plants and long-term conservation of the recombinant enzyme. Protoplasma 251:639-648

Petersen K, Bock R (2011) High-level expression of a suite of thermostable cell wall-degrading enzymes from the chloroplast genome. Plant Mol Biol 76:311-321

Pipia I, Kunelauri N, Gogniashvili M, Kotaria N, Kotorashvili A, Lacombe T, Tabidze V(2017). Complete plastid genomes of South Caucasian, European and Mediterranean Basin wild grapevines (Vitis vinifera subsp. sylvestris). Acta Horticult 1188. ISHS 2017. https://doi. org/10.17660/ActaHortic.2017.1188.47

Poage M, Le Martret B, Jansen MA, Nugent GD, Dix PJ (2011) Modification of reactive oxygen species scavenging capacity of chloroplasts through plastid transformation. Plant Mol Biol 76:371-384

Qian J, Song J, Gao H, Zhu Y, Xu J, Pang X, Yao H, Sun C, Li X, Li C, Liu J, Xu H, Chen S (2013) The complete chloroplast genome sequence of the medicinal plant Salvia miltiorrhiza. PLoS One 8:e57607

Raveendar S, Na YW, Lee JR, Shim D, Ma KH, Lee SY, Chung JW (2015) The complete chloroplast genome of Capsicum annuиm var. glabriusculum using Illumina sequencing. Molecules 20:13080-13088

Rigano MM, Manna C, Giulini A, Pedrazzini E, Capobianchi M, Castilletti C, Di Caro A, Ippolito G, Beggio P, De Giuli MC, Monti L, Vitale A, Cardi T (2009) Transgenic chloroplasts are efficient sites for high-yield production of the vaccinia virus envelope protein A27L in plant cellsdagger. Plant Biotechnol J 7:577-591

Rigano M, Scotti N, Cardi T (2012) Unsolved problems in plastid transformation. Bioengineered 3:329-333

Rogalski M, do Nascimento Vieira L, Fraga HP, Guerra MP (2015) Plastid genomics in horticultural species: importance and applications for plant population genetics, evolution, and biotechnology. Front Plant Sci 6:586

Roney J, Khatibi P, Westwood J (2007) Cross-species translocation of mRNA from host plants into the parasitic plant dodder. Plant Physiol 143:1037-1043

Rubio-Infante N, Govea-Alonso DO, Alpuche-Solís ÁG, García-Hernández AL, Soria-Guerra RE, Paz-Maldonado LM, Ilhuicatzi-Alvarado D, Varona-Santos JT, Verdín-Terán L, Korban SS, Moreno-Fierros L, Rosales-Mendoza S (2012) A chloroplast-derived C4V3 polypeptide from the human immunodeficiency virus (HIV) is orally immunogenic in mice. Plant Mol Biol 78:337-349

Rubio-Infante N, Govea-Alonso DO, Romero-Maldonado A, García-Hernández AL, IlhuicatziAlvarado D, Salazar-González JA, Korban SS, Rosales-Mendoza S, Moreno-Fierros L (2015) A plant-derived multi-hiv antigen induces broad immune responses in orally immunized mice. Mol Biotechnol 57:662-674 
Ruhlman T, Lee SB, Jansen RK, Hostetler JB, Tallon LJ, Town CD, Daniell H (2006) Complete plastid genome sequence of Daucus carota: implications for biotechnology and phylogeny of angiosperms. BMC Genomics 7:222

Ruhlman T, Ahangari R, Devine A, Samsam M, Daniell H (2007) Expression of cholera toxin B-proinsulin fusion protein in lettuce and tobacco chloroplasts: oral administration protects against development of insulitis in non-obese diabetic mice. Plant Biotechnol J 5:495-510

Ruhlman TA, Rajasekaran K, Cary JW (2014) Expression of chloroperoxidase from Pseudomonas pyrrocinia in tobacco plastids for fungal resistance. Plant Sci 228:98-106

Samson N, Bausher MG, Lee SB, Jansen RK, Daniell H (2007) The complete nucleotide sequence of the coffee (Coffea arabica L.) chloroplast genome: organization and implications for biotechnology and phylogenetic relationships amongst angiosperms. Plant Biotechnol J 5 339-353

Saski C, Lee SB, Daniell H, Wood TC, Tomkins J, Kim HG, Jansen RK (2005) Complete chloroplast genome sequence of Gycine max and comparative analyses with other legume genomes. Plant Mol Biol 59:309-322

Saski C, Lee SB, Fjellheim S, Guda C, Jansen RK, Luo H, Tomkins J, Rognli OA, Daniell H, Clarke JL (2007) Complete chloroplast genome sequences of Hordeum vulgare, Sorghum bicolor and Agrostis stolonifera, and comparative analyses with other grass genomes. Theor Appl Genet 115(4):571-590

Sato S, Nakamura Y, Kaneko T, Asamizu E, Tabata S (1999) Complete structure of the chloroplast genome of Arabidopsis thaliana. DNA Res 6:283-290

Schmitz-Linneweber C, Maier RM, Alcaraz JP, Cottet A, Herrmann RG, Mache R (2001) The plastid chromosome of spinach (Spinacia oleracea): complete nucleotide sequence and gene organization. Plant Mol Biol 45:307-315

Scotti N, Alagna F, Ferraiolo E, Formisano G, Sannino L, Buonaguro L, De Stradis A, Vitale A, Monti L, Grillo S, Buonaguro FM, Cardi T (2009) High-level expression of the HIV-1 Pr55gag polyprotein in transgenic tobacco chloroplasts. Planta 229:1109-1122

Sharifi Tabar M, Habashi AA, Rajabi Memari H (2013) Human granulocyte colony-stimulating factor (hG-CSF) expression in plastids of Lactuca sativa. Iran Biomed J 17:158-164

Shen X, Wu M, Liao B, Liu Z, Bai R, Xiao S, Li X, Zhang B, Xu J, Chen S (2017) Complete chloroplast genome sequence and phylogenetic analysis of the medicinal plant Artemisia annua. Molecules 22 pii:E1330

Shimizu M, Goto M, Hanai M, Shimizu T, Izawa N, Kanamoto H, Tomizawa K, Yokota A, Kobayashi H (2008) Selectable tolerance to herbicides by mutated acetolactate synthase genes integrated into the chloroplast genome of tobacco. Plant Physiol 14:1976-1983

Shinozaki K, Ohme M, Tanaka M, Wakasugi T, Hayashida N, Matsubayashi T, Zaita N, Chunwongse J, Obokata J, Yamaguchi-Shinozaki K, Ohto C, Torazawa K, Meng BY, Sugita M, Deno H, Kamogashira T, Yamada K, Kusuda J, Takaiwa F, Kato A, Tohdoh N, Shimada H, Sugiura M (1986) The complete nucleotide sequence of the tobacco chloroplast genome: its gene organization and expression. EMBO J 5:2043-2049

Soria-Guerra RE, Alpuche-Solís AG, Rosales-Mendoza S, Moreno-Fierros L, Bendik EM, Martínez-González L, Korban SS (2009) Expression of a multi-epitope DPT fusion protein in transplastomic tobacco plants retains both antigenicity and immunogenicity of all three components of the functional oligomer. Planta 229:1293-1302

Steane DA (2005) Complete nucleotide sequence of the chloroplast genome from the Tasmanian blue gum, Eucalyptus globulus (Myrtaceae). DNA Res 12:215-220

Su J, Zhu L, Sherman A, Wang X, Lin S, Kamesh A, Norikane JH, Streatfield SJ, Herzog RW, Daniell H (2015) Low cost industrial production of coagulation factor IX bioencapsulated in lettuce cells for oral tolerance induction in hemophilia B. Biomaterials 70:84-93

Svab Z, Maliga P (1993) High-frequency plastid transformation in tobacco by selection for a chimeric aadA gene. Proc Nat Acad Sci USA 90:913-917

Svab Z, Hajdukiewicz P, Maliga P (1990) Stable transformation of plastids in higher plants. Proc Nat Acad Sci USA 87:8526-8530

Talianova M, Janousek B (2011) What can we learn from tobacco and other Solanaceae about horizontal DNA transfer? Am J Bot 98:1231-1242 
Tang J, Xia H, Cao M, Zhang X, Zeng W, Hu S, Tong W, Wang J, Wang J, Yu J, Yang H, Zhu L (2004) A comparison of rice chloroplast genomes. Plant Physiol 135:412-420

Tangphatsornruang S, Sangsrakru D, Chanprasert J, Uthaipaisanwong P, Yoocha T, Jomchai N, Tragoonrung S (2010) The chloroplast genome sequence of mungbean (Vigna radiata) determined by high-throughput pyrosequencing: structural organization and phylogenetic relationships. DNA Res 17:11-22

Tangphatsornruang S, Uthaipaisanwong P, Sangsrakru D, Chanprasert J, Yoocha T, Jomchai N, Tragoonrung S (2011) Characterization of the complete chloroplast genome of Hevea brasiliensis reveals genome rearrangement, RNA editing sites and phylogenetic relationships. Gene 475:104-112

Timme RE, Kuehl JV, Boore JL, Jansen RK (2007) A comparative analysis of the Lactuca and Helianthus (Asteraceae) plastid genomes: identification of divergent regions and categorization of shared repeats. Am J Bot 94:302-312

Tong W, Kim TS, Park YJ (2016) Rice chloroplast genome variation architecture and phylogenetic dissection in diverse oryza species assessed by whole-genome resequencing. Rice 9:57

van Eerde A, Gottschamel J, Bock R, Hansen KEA, Munang' andu HM, Daniell H, Liu Clarke J (2018) Production of tetravalent dengue virus envelope protein domain III based antigens in lettuce chloroplasts and immunologic analysis for future oral vaccine development. Plant Biotechnol J 17:1408. https://doi.org/10.1111/pbi.13065

Vaughn JN, Chaluvadi SR, Tushar, Rangan L, Bennetzen JL (2014) Whole plastome sequences from five ginger species facilitate marker development and define limits to barcode methodology. PLoS One 9(10):e108581

Vergara D, White KH, Keepers KG, Kane NC (2016) The complete chloroplast genomes of Cannabis sativa and Humulus lupulus. Mitochond DNA A DNA Mapp Seq Anal. 27:3793-3794

Verma D, Daniell H (2007) Chloroplast vector systems for biotechnology applications. Plant Physiol 145:1129-1143

Verma D, Kanagaraj A, Jin S, Singh ND, Kolattukudy PE, Daniell H (2010) Chloroplast-derived enzyme cocktails hydrolyse lignocellulosic biomass and release fermentable sugars. Plant Biotechnol J 8:332-350

Verma D, Jin S, Kanagaraj A, Singh ND, Daniel J, Kolattukudy PE, Miller M, Daniell H (2013) Expression of fungal cutinase and swollenin in tobacco chloroplasts reveals novel enzyme functions and/or substrates. PLoS One 8:e57187

Viitanen PV, Devine AL, Khan MS, Deuel DL, Van Dyk DE, Daniell H (2004) Metabolic engineering of the chloroplast genome using the Echerichia coli ubiC gene reveals that chorismate is a readily abundant plant precursor for p-hydroxybenzoic acid biosynthesis. Plant Physiol 136:4048-4060

Wang YP, Wei ZY, Zhong XF, Lin CJ, Cai YH, Ma J, Zhang YY, Liu YZ, Xing SC (2015) Stable expression of basic fibroblast growth factor in chloroplasts of tobacco. Intl J Mol Sci 17:pii: E19

Wani SH, Haider N, Kumar H, Singh NB (2010) Plant plastid engineering. Curr Genomics 11:500-512

Westwood JH, Yoder JI, Timko MP, dePamphilis CW (2010) The evolution of parasitism in plants. Trends Plant Sci 15:227-235

Wu Z (2016) The completed eight chloroplast genomes of tomato from Solanum genus. Mitochond DNA A DNA Mapp Seq Anal. 27:4155-4157

Wu Z, Ge S (2016) The whole chloroplast genome of wild rice (Oryza australiensis). Mitochond DNA A DNA Mapp Seq Anal. 27:1062-1063

Wu ML, Li Q, Xu J, Li XW (2018) Complete chloroplast genome of the medicinal plant Amomum compactum: gene organization, comparative analysis, and phylogenetic relationships within Zingiberales. Chin Med 13:10

Wurbs D, Ruf S, Bock R (2007) Contained metabolic engineering in tomatoes by expression of carotenoid biosynthesis genes from the plastid genome. Plant J 49:276-288 
Yabuta Y, Tanaka H, Yoshimura S, Suzuki A, Tamoi M, Maruta T, Shigeoka S (2013) Improvement of vitamin E quality and quantity in tobacco and lettuce by chloroplast genetic engineering. Transgenic Res 22:391-402

Yanez RJR, Lamprecht R, Granadillo M, Torrens I, Arcalís E, Stöger E, Rybicki EP, Hitzeroth II (2018) $\mathrm{LALF}_{32-51}$-E7, a HPV-16 therapeutic vaccine candidate, forms protein body-like structures when expressed in Nicotiana benthamiana leaves. Plant Biotechnol J 16:628-637

Yu L-X, Gray BN, Rutzke CJ, Walker LP, Wilson DB, Hanson MR (2007) Expression of thermostable microbial cellulases in the chloroplasts of nicotine-free tobacco. J Biotechnol 131:362-369

Yu Y, Lee H-O, Chin JH, Park YH, Yoo S-C (2017) The complete chloroplast genome sequence of Oryza sativa aus-type variety Nagina-22 (Poaceae). Mitochond DNA Part B Resour 2:819-820

Zhang J, Tan W, Yang XH, Zhang HX (2008) Plastid-expressed choline monooxygenase gene improves salt and drought tolerance through accumulation of glycine betaine in tobacco. Plant Cell Rep 27:1113-1124

Zhang XH, Keating P, Wang XW, Huang YH, Martin J, Hartmann JX, Liu A (2014) Production of functional native human interleukin-2 in tobacco chloroplasts. Mol Biotechnol 56:369-376

Zhang J, Khan SA, Hasse C, Ruf S, Heckel DG, Bock R (2015) Pest control. Full crop protection from an insect pest by expression of long double-stranded RNAs in plastids. Science 347:991-994

Zhang D, Li K, Gao J, Liu Y, Gao L-Z (2016) The complete plastid genome sequence of the wild rice Zizania latifolia and comparative chloroplast genomics of the rice tribe oryzeae, poaceae. Frontiers in. Plant Sci. https://doi.org/10.3389/fevo.2016.00088

Zhang H, Jin J, Moore MJ, Yi T, Li D (2018a) Plastome characteristics of Cannabaceae. Plant Diversity 40:127-137

Zhang X, Rong C, Qin L, Mo C, Fan L, Yan J, Zhang M (2018b) Complete chloroplast genome sequence of Malus hupehensis: genome structure, comparative analysis, and phylogenetic relationships. Molecules 23:pii: E2917

Zhou YX, Lee MY, Ng JM, Chye ML, Yip WK, Zee SY, Lam E (2006) A truncated hepatitis E virus ORF2 protein expressed in tobacco plastids is immunogenic in mice. World J Gastroenterol 12:306-312

Zhou F, Badillo-Corona JA, Karcher D, Gonzalez-Rabade N, Piepenburg K, Borchers AM, Maloney AP, Kavanagh TA, Gray JC, Bock R (2008) High-level expression of human immunodeficiency virus antigens from the tobacco and tomato plastid genomes. Plant Biotechnol J 6:897-913 